\title{
RAPD Based Genetic Diversity Analysis Within The Genus Solanum
}

\author{
SH.M. Ahmed ${ }^{1} *$ and M.A. Fadl ${ }^{2}$ \\ ${ }^{1}$ Biology Department, Faculty of Education, Ain Shams \\ University, Cairo and ${ }^{2}$ Botany Department, Faculty of \\ Science, Beni-Suef University, Beni-Suef, Egypt
}

\begin{abstract}
OLANUM L., the largest genus of the Solanaceae family, varies $\$$ morphologically and is ecogeographically distributed. In Saudi Arabia, previous studies for characterization and genetic variability of Solanum had focused mainly on chromosome morphology, genome description and medicinal values, which are insufficient for genetic affinities. This investigation assessed molecular diversity of some species of Solanum from Taif highlands based on random amplified polymorphic DNA markers and proteins by SDS-PAGE. From 25 random primers investigated, 11 primers gave reproducible amplification banding patterns of 208 polymorphic bands scoring $100 \%$ polymorphism across the genotypes. Primer OPA-09 generated maximum polymorphic pattern, whereas primers OPP-10, OPN-13 and $\mathrm{OPN}-05$ produced minimum polymorphism. The size of the amplified products varied from 265 to $2003 \mathrm{bp}$. SDS denatured protein gels resolved 51bands most of them were not shared and some were unique and can be correlated with the DNA polymorphism. Based on these markers, genetic similarity coefficient was calculated and a dendrogram was constructed.
\end{abstract}

Keywords: Solanum, RAPD, Electrophoresis, Genetic relationships.

Solanum L., a complex and large genus of the family Solanaceae contains roughly between 1,500 and 2,000 species (Bohs, 2001). In Saudi Arabia, the genus is represented by about 16 species, mainly in West and Southwest side of the country (Chaudhary, 2001 and Collenette, 1999).

Limited work has been done on the nature of genetic diversity and characterization of wild and cultivated Solanum, especially using molecular methods. Taxonomic studies on Solanum species have been based on chromosome morphology (AlWadi \& Lashin 2007), medicinal and food values (Al-Oqail et al., 2012). These have not resolved the problems of synonymy and taxa misidentification common to the genus in Saudi Arabia. Molecular biology has revolutionized the field of plant systematics and has been used successfully in phylogenetic relationships at all taxonomic levels (Bohs, 2005) as well as in genetic diversity studies (Isshiki et al., 2008). Random amplified polymorphic DNA (RAPD), when compared with other molecular markers, is more effective in this regard as it is simple, rapid, requires only a small quantity of DNA and it is well adapted for nonradioactive DNA fingerprinting of genotypes (Cao et al., 1999). It is also able to generate numerous polymorphisms

*Corresponding author: shamahmoh@gmail.com 
(Williams et al., 1990). Karihaloo et al. (1995) focused directly on nuclear genomic diversity of Solanum by undertaking RAPD analysis. Karihaloo and Gottlieb (1995) also reported that greater DNA polymorphism exists in weedy Solanum incanum than in advanced cultivars of eggplants. RAPD data of Solanum was used in several other studies such as Miller \& Spooner (1999), Stedje \& Bukenya-Ziraba (2003) and Singh et al. (2006) to clarify phylogenetic relationships.

Therefore, RAPD-PCR and protein electrophoresis (SDS-PAGE) techniques will be utilized for better characterization of some Solanum species of Taif highlands as well as studying the genetic relationships among them.

\section{Material and Methods}

Fresh leaves (young and matured) of one cultivar; Solanum lycopersicum L., two wild accessions of S. incanum L.(from two localities; Alshafa \& Sasied) and five wild species; S. nigrum L., S. schimperianum Hochst, S. glabratum var. sepicula Dunal, S. albicaule Kotschy ex Dunal and_Solanum sp., were collected from Taif highlands of Saudi Arabia (Longitude $40^{\circ} 18^{\prime} 270^{\prime \prime}-40^{\circ} 29^{\prime} 820^{\prime \prime} \mathrm{E}$ and Latitude $\left.21^{\circ} 5^{\prime} 290^{\prime \prime}-21^{\circ} 17^{\prime} 750^{\prime \prime} \mathrm{N}\right)$ as shown in Fig.1.The collected materials were identified according to Collenette (1999) and Chaudhary (2001).

Total genomic DNA was extractedfrom young fresh leaves using Wizard genomic DNA purification kit (Promega Corporation, USA). Verification of the quality of the purified DNA samples was achieved by electrophoresis on a $1 \%$ Agarose gel. Twenty five random primers (Oligo Macrogen Inc., South Korea) were screened. Only 11 that are highly polymorphic and gave reproducible bands were selected and used in the analysis of all Solanum genotypes. Total reaction volume for PCR was $25 \mu \mathrm{l}$ containing $0.1 \mu \mathrm{l}$ of primer, $1 \mu \mathrm{l}$ of $10 \mathrm{mg} / \mu \mathrm{l}$ sample DNA, $12.5 \mu \mathrm{l}$ Green Master Mix (Promega corporation, USA) and $11.4 \mu \mathrm{l}$ of distilled water. Amplification was accomplished on the Techne TC- 3000 thermal cycler (Model FTC41H2D, Barloworld Scientific Ltd, Staffordshire, UK) using the following temperature profile: Initial strand separation step of $5 \mathrm{~min}$ at $94^{\circ} \mathrm{C}$ followed by 40 cycles each consisting of a denaturing step of $1 \mathrm{~min}$. at $94^{\circ} \mathrm{C}$, annealing step of $30 \mathrm{sca}$. at $36^{\circ} \mathrm{C}$ and an extension step of $2 \mathrm{~min}$. at $72^{\circ} \mathrm{C}$. The last cycle was followed by $7 \mathrm{~min}$. extension at $72^{\circ} \mathrm{C}$ to allow complete extension of the PCR products with a final hold at $4^{\circ} \mathrm{C}$ till electrophoresis. $7 \mu$ l of each of PCR product (amplicon) were mixed with $3 \mu \mathrm{l}$ of $10 \mathrm{X}$ loading dye $(0.25 \%$ bromophenol blue, $0.25 \%$ xylene cyanol and $40 \%$ sucrose, w/v) and spun briefly in a micro centrifuge before loading on a1.2\% agarose gel which has been previously stained with safe view. This was run for $37 \mathrm{~min}$. at $110 \mathrm{~V} / \mathrm{cm}$. Thereafter, the gel was viewed (with the aid of eye protector) and photographed in the Gel Documentation and Analysis Systems (Gel Doc-It ${ }^{\mathrm{TM}}$ 300, UltraViolet Products Ltd., Cambridge, UK). 
SDS-PAGE was performed in $12 \%$ acrylamide slab gels (C.B.S. Scientific, USA) following the system of Laemmli (1970). Protein extraction was conducted by grinding $1 \mathrm{~g}$ of leaves of each sample in $1 \mathrm{ml}$ of $1.5 \mathrm{M}$ Tris-HCl buffer, $\mathrm{pH} 8.8$ using a mortar and pestle. The homogenatewas centrifuged at 1000 rpm for $10 \mathrm{~min}$. The clear supernatant was transferred to clean Eppendorf tube and kept at $-20^{\circ} \mathrm{C}$ until use. For electrophoresis, $20 \mu \mathrm{l}$ of supernatant was mixed with $10 \mu \mathrm{l}$ of loading dye and $20 \mu \mathrm{l}$ of mixture was loaded in the gel for each sample. After the run completed, the gel was stained, destained and photographed.

Differences in bands intensity among profiles of the different samples were not considered. The produced clear well defined bands are used to estimate levels of polymorphism by dividing the polymorphic bands by the total number of scored bands. Then the presence or absence of each RAPD and protein band was treated as a binary character in a data matrix (coded 1 and 0 , respectively) to calculate genetic similarity and to construct dendrogram among the 8 samples. Data generated by RAPD-PCR and SDS-PAGE was used to compile a binary matrix for cluster analysis. Genetic similarity among species was calculated according to Dice similarity coefficient (Dice, 1945) and used to construct a dendrogram using unweighted pair group method with arithmetic average (UPGMA) using SPSS-20 program (SPSS, 2011).

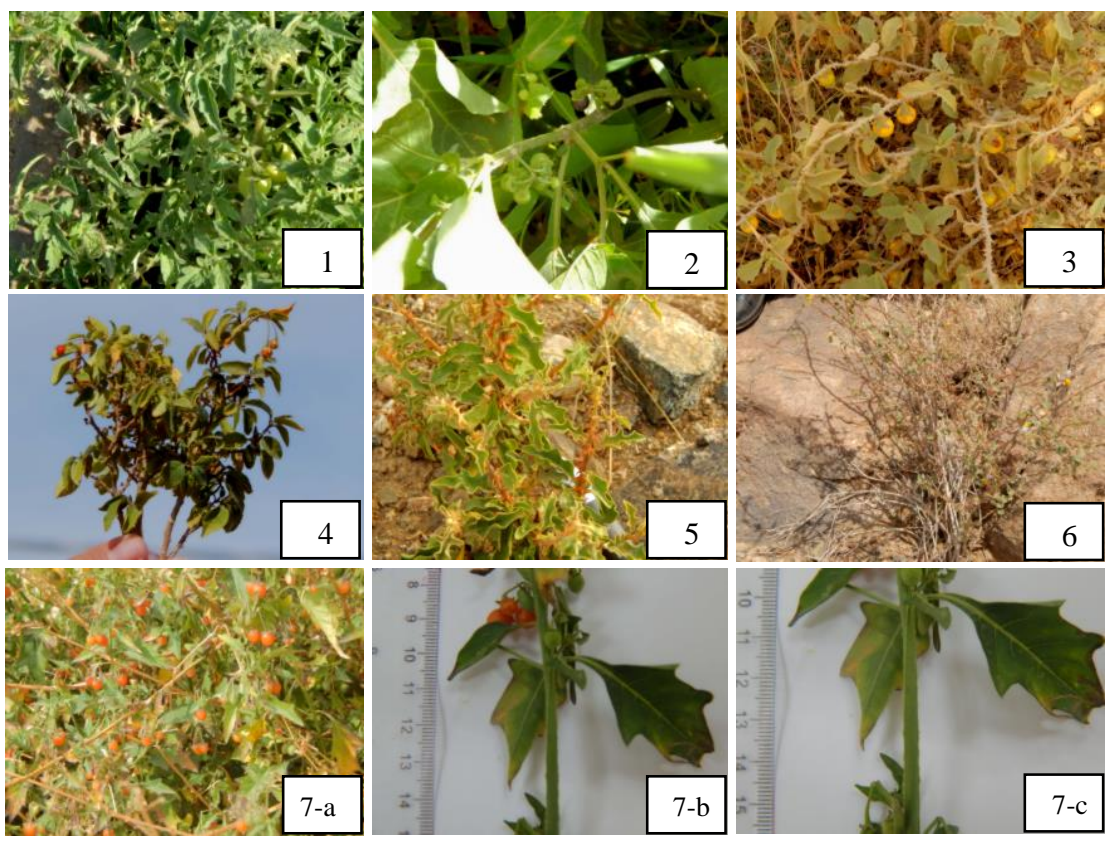

Fig. 1. Collected Solanum species fromTaif highlands of Saudi Arabia. 1: $S$. lycopercum, 2: S. nigrum, 3: S. incanum 4: S. schimperianum, 5: $S$. glabratum var. sepicula, 6: S. albicaule, 7-a,b\&c: Solanum sp. 


\section{Results}

Table 1. and Fig. 2 revealed that the selected 11 RAPD primers allowed us to obtain 208 DNA fragments, an average 18.9 per primer. OPP-10, OPN-13 and OPN-05 primers gave the fewest bands (14 fragments) and OPA-09 the most (29 fragments). All detected DNA fragments were polymorphic with polymorphism percentage $100 \%$ for all investigated primers. RAPD analysis revealed no band in $S$. lycopersicum in primer OPP-10, $S$. incanum (Alshafa) in primers OPP-10, OPN-13, OPN-10 \& OPN-08, Solanum sp. in primer OPN-13 and S. albicaule in primer OPA-02 (Fig. 3). Each species showed specific characteristic RAPD fingerprinting through all studied primers. RAPD profiles recorded 135 unique bands; 19 in $S$. lycopersicum, 15 in S. nigrum, 3 in S. incanum (Alshafa), 14 in S. incanum (Sasied), 23 in S. schimperianum, 26 in S. glabratum var. sepicula, 11 in Solanum sp. and 24 in S. albicaule, that could be used to discriminate the respective species.

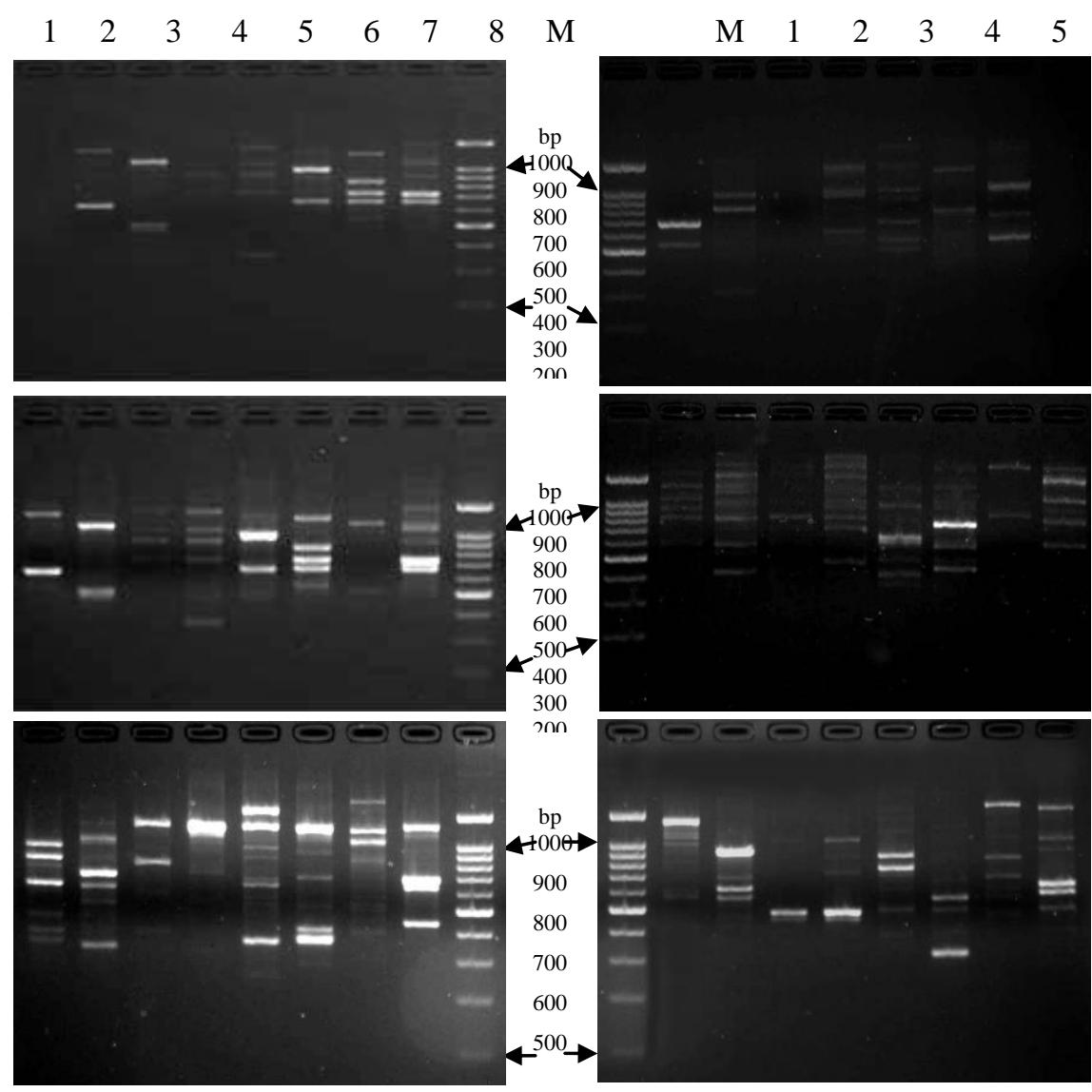

Fig. 3. APD profiles of Solanum species generated by the 1:OPP-10, 2:OPA-02, 3:OPP-09, 4:OPA-01, 5:OPN-16 and 6:OPA-09 primers; $M=$ Marker. 1: $S$. lycopersicum , 2: $S$. nigrum, 3: S. incanum (Alshafa), 4: S. incanum (Sasied), 5: S. schimperianum, 6: S. glabratum var. sepicula, 7: Solanum sp, 8: S. albicaule.

Egypt. J. Bot., Vol. 55, No. 2 (2015) 
TABLE 1. Operon primers selected with their nucleotide sequence, number and types of the amplified DNA bands as well as the percentage of the total polymorphism generated by 11 RAPD primers in Solanum species.

\begin{tabular}{|c|c|c|c|c|c|}
\hline \multirow{2}{*}{$\begin{array}{c}\text { Primer } \\
\text { code }\end{array}$} & \multirow{2}{*}{$\begin{array}{c}\text { Primer sequence } \\
(\mathbf{5} \text { - - 3') }\end{array}$} & \multicolumn{2}{|c|}{ Polymorphic band } & \multirow{2}{*}{$\begin{array}{c}\text { Total } \\
\text { band }\end{array}$} & $\begin{array}{c}\text { Polymorphism } \\
(\boldsymbol{\%})\end{array}$ \\
& Unique & $\begin{array}{c}\text { Not } \\
\text { shared }\end{array}$ & & 10 & 100 \\
\hline OPA-01 & CAGGCCCTTC & 15 & 10 & 25 & 100 \\
\hline OPA-02 & TGCCGAGCTG & 9 & 7 & 16 & 100 \\
\hline OPP-10 & TCCCGCCTAC & 9 & 5 & 14 & 100 \\
\hline OPP-09 & GTGGTCCGCA & 11 & 7 & 18 & 100 \\
\hline OPN-13 & AGCGTCACTC & 10 & 4 & 14 & 100 \\
\hline OPN-10 & ACAACTGGGG & 16 & 3 & 19 & 100 \\
\hline OPN-09 & TGCCGGCTTG & 8 & 7 & 15 & 100 \\
\hline OPN-08 & ACCTCAGCTC & 12 & 4 & 16 & 100 \\
\hline OPN-05 & ACTGAACGCC & 10 & 4 & 14 & 100 \\
\hline OPN-16 & AAGCGACCTG & 17 & 11 & 28 & 100 \\
\hline OPA-09 & GGGTAACGCC & 18 & 11 & 29 & \\
\hline
\end{tabular}

The Solanum genotypes exhibited substantial changes in protein levels as shown in Fig. 3. SDS denatured protein gels resolved a total of 51 bands. Highest number of protein bands was observed in S. incanum (Sasied). Using gel analyzer 3 software the molecular weight and the $\mathrm{Rf}$ value of each band was calculated. These SDS protein bands had different molecular weights ranging from $155.2 \mathrm{kDa}$ to $13.9 \mathrm{kDa}$. Two bands at 56.3 and $40.8 \mathrm{kDa}$ were shared by all species. The profile revealed 49 polymorphic bands with polymorphism percentage $96 \%$. From them 23 unique bands; one in S. schimperianum \& $S$. albicaule, two in S. nigrum, S. incanum (Alshafa) \&_Solanum sp., four in $S$. lycopersicum \& S. glabratum var. sepicula and seven in S. Incanum (Sasied).

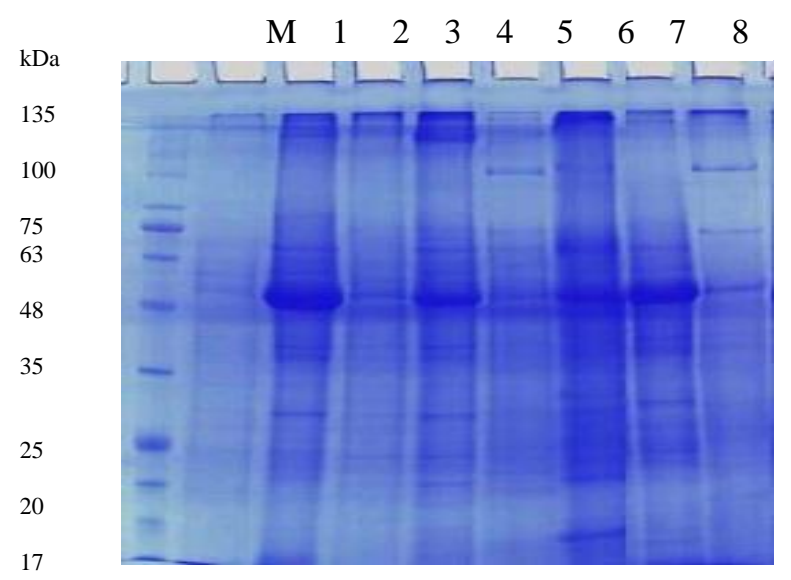

Fig. 2. The produced seed protein profile of Solanum species using SDS-PAGE technique. M: Standard protein marker, kDa: kilo Dalton. 1: S. lycopersicum , 2: S. nigrum, 3: $S$. incanum (Alshafa), 4: S. incanum (Sasied), 5: S. schimperianum, 6: S. glabratum var. sepicula, 7:_Solanum sp, 8: S. albicaule. 
Genetic similarity was calculated from the dice similarity index value for all species of Solanum. Based on RAPD and protein markers, The maximum genetic similarity was 0.46 between the two accessions of $S$. incanum. while the lowest genetic similarity of 0.13 was between $S$. lycopersicum and $S$. glabratum var. sepicula (Table 2). The phylogenetic relationships among Solanum species were analyzed by UPGMA method (Fig. 4). The cluster result indicated that all species could be distinguished by RAPD and protein markers, respectively. A dendrogram based on UPGMA analysis grouped the 8 taxa into one main cluster and the cultivar S. lycopersicum formed a separate operational taxonomic units (OTU) in cluster showing less similarity coefficient with the other wild taxa. Species within main cluster were further divided into three subclusters (IIa, IIb and IIc). Subcluster IIa comprised the two accessions of S. incanum. Subcluster IIb comprised S. glabratum var. sepicula with S. albicaule. Cluster IIc grouped Solanum sp. with S. nigrum and S. schimperianum.

TABLE 2: Dice similarity coefficient of Solanum species based on RAPD and SDS-

PAGE data analysis.
\begin{tabular}{|l|c|c|c|c|c|c|c|c|}
\hline & $\begin{array}{c}\text { S. } \\
\text { lyco. }\end{array}$ & $\begin{array}{c}\text { S. } \\
\text { nig. }\end{array}$ & $\begin{array}{c}\text { S. } \\
\text { inc. (Al) }\end{array}$ & $\begin{array}{c}\text { S. } \\
\text { inc. (Sa) }\end{array}$ & $\begin{array}{c}\text { S. } \\
\text { schim. }\end{array}$ & $\begin{array}{c}\text { S. } \\
\text { glab. }\end{array}$ & $\begin{array}{c}\text { S. } \\
\text { sp. }\end{array}$ & $\begin{array}{c}\text { S. } \\
\text { alb. }\end{array}$ \\
\hline S. lyco. & 1.000 & & & & & & & \\
\hline S. nig & .189 & 1.000 & & & & & & \\
\hline S. inc. (Al) & .139 & .200 & 1.000 & & & & & \\
\hline S. Inc. (Sa) & .131 & .256 & .462 & 1.000 & & & & \\
\hline S. schim. & .150 & .320 & .198 & .238 & 1.000 & & & \\
\hline S. glab. & .127 & .266 & .191 & .202 & .233 & 1.000 & & \\
\hline S. sp. & .146 & .281 & .200 & .296 & .261 & .237 & 1.000 & \\
\hline S. alb. & .154 & .252 & .158 & .250 & .235 & .288 & .256 & 1.000 \\
\hline
\end{tabular}

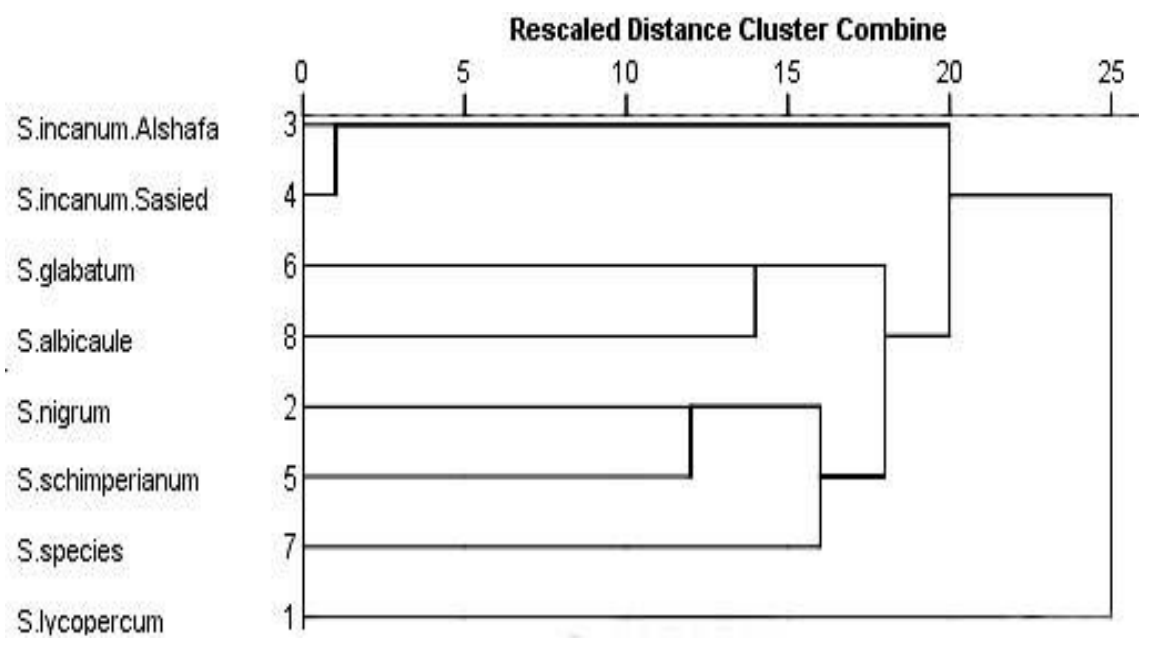

Fig. 4. UPGMA phenogram showing genetic diversity of Solanum species based on combination of RAPD and SDS-PAGE bands.

Egypt. J. Bot., Vol. 55, No. 2 (2015) 


\section{Discussion}

RAPD analysis provided insight into the genetic diversity of some species of Solanum in Taif. RAPD markers had the greatest advantage of its capability to scan across all regions of the genome hence highly suited for phylogeny studies at species level (Viorel et al., 2009; Zabihollah et al., 2012). These markers revealed considerable genetic diversity among the species through a minimal profile for each species allowing them to be differentiated from each other, a finding which strongly agrees with the great morphological variability observed. These findings agreed with those of Li et al. (2010) and Singh et al. (2006). The High degree of diversity of species belonging to Solanum may be attributable in part to the use of different RAPD primers, ecology, difference in their reproductive biology as the species was insect pollinated, or to the fact that it is an ancient plant (Whalen, 1979). Furthermore, RAPD analysis revealed no band in some species, due to the absence of those sequences in these species. Similar finding has been reached by Alam et al. (2012).

During protein profiling of total proteins of experimental species, 51 seed protein bands including 23 unique bands with polymorphism percentage of $96 \%$ were observed. This revealed a characteristic variability among the Solanum taxa that may be due to environmental factors which affected the qualitative and quantitative attributes of leaves proteins. This was in accordance with the data of Hasan and Isa (1998) who reported a great variability in seed protein profiles in eggplant cultivar (Solanum melongena L.) and its nearest wild species; S. cumingii Dun., $S$. insanum L. and $S$. incanum L. Finding out intergeneric or interspecific correlation among members of family Solanaceae using SDS-PAGE had been done by several earlier workers e.g. Scheadai et al. (2002), Karihaloo et al. (2004), Bhat \& Kudesia (2011) and Florina (2012).

Using cluster analysis, solanum species are categorized into one main cluster including wild species and one ungrouped cultivar (Solanum lycopersicum L. var. lycopersicum) formed a separate OTU in cluster. Similar results were obtained by Hasan \& Isa (1998) and Singh et al. (2006). Sandra et al. (2014) revealed that Bayesian analysis clustered all individuals of genus Corylus into three groups showing a good separation among wild genotypes, landraces and cultivars. Our data revealed the close relationship between S. glabratum var. sepicula and $S$. albicaule. On the other hand, the unknown wild species was more closely related to $S$. nigrum and $S$. schimperianum than other species. The previous data was in accordance with Jaeger (1985) who reported that Solanum lycopersicum L. var. lycopersicum is belonging to subgenus Potatoe section Petota subsection Lycopersicon ser. Neolycopersicon, while S. albicaule Dunal and Solanum glabratum var. sepicula (Dunal) J.R.I. Wood are belonging to subgenus Leptostemonum section Oliganthes, Solanum incanum L. is also belonging to subgenus Leptostemonum section Melongena, and disagreed in case of Solanum schimperianum Hochst. ex Dunal that belonged to subgenus Leptostemonum section Giganteiformia. 
The present study suggested a new species of Solanum in Taif highlands, that needed more investigation to be identified. The distinguishing morphological characters were shrub up to $1.5 \mathrm{~m}$ unarmed with irregular tree like hairs (denditric hairs); stem striated with small dents on the ribs; leaves petiolate (up to $1.5 \mathrm{~cm}$ ), ovate-hastate lobed with entire margin, $3.5-4.5 \times 2.5-3 \mathrm{~cm}$, leaf apex acute-acuminate, veins green, flowers have white petals with violet midrib, 4-5 stamens, yellow colour anthers, fruits aggregates on umbellate clusters of 4-5 fruits, fruiting peduncle up to $2 \mathrm{~cm}$ and directed upward, pedicels reflexed of $1 \mathrm{~cm}$ long, sepals persist and reflexed; fruits are dull orange of $0.8-0.9 \mathrm{~cm}$ diameter, seeds dull yellow striated, $0.7-9 \mathrm{~mm}$ diameter. The morphological and molecular characters of unknown species showed marked relation to subgenus Solanum. High level of polymorphism was observed going by the coefficient of variation which exhibited a good separation from a conserved region of the genome. This revealed a wide and diverse genetic base in Saudi Arabian Solanum. Knowledge of molecular relationships between plant species is very useful in planning effective breeding strategies designed to transfer desirable genes or gene clusters from one species into another, thereby producing fruitful genomic reconstructions and disease free plants.

In conclusion, species database of some wild species of Solanum was provided in Taif of Saudi Arabia with emphasis on variation patterns which was a major contribution to global biodiversity information system. It was evident that RAPD and other discontinuous markers could be used as a means of genetic distances to establish Solanum taxonomy as well as phylogenetic relationships among taxa.

\section{References}

Alam, S. S., Ishrat, E., Zzaman, M. and Habib, M. (2012) Comparative karyotype and RAPD analysis for characterizing three varieties of Lycopersicon esculentum mill. Bangladesh j. Bot., 41(2), 149-154.

Al-Oqail, M., Hassan, W. H.B. and Al-Rehaily A.J. (2012) Phytochemical and biological studies of Solanum schimperianum Hochst. Saudi Pharmaceutical Journal, 20 (4), 371-379.

Al-Wadi, H.M. and Lashin, G.M.A. (2007) Palynological and cytological characters of three species of genus Solanum (Family: Solanaceae) from Saudi Arabia. Journal of Biological Sciences, 7, 626-631.

Bhat, T.M., and Kudesia, R. (2011) Evaluation of genetic diversity in five different species of family Solanaceae using cytological characters and protein profiling. Genetic Engineering and Biotechnology Journal, 2011, 1-8.

Bohs, L. (2001) Revision of Solanum section Cyphomandropsis (Solanaceae). Syst. Bot. Monogr, 61, 1-85.

Egypt. J. Bot., Vol. 55, No. 2 (2015) 
Bohs, L. (2005) "Major Clades in Solanum Based on ndhF Sequence Data." Keating, R. C., Hollowell, V. C. and Croat, T. B. (Eds.). A festschrift for William G. D'Arcy: the legacy of a taxonomist. St. Louis Monogr.

Cao, W., Scoles, G., Huc, L. P. and Chibbar, R. N. (1999) The use of RAPD analysis to classify Triticum accessions. Theor. Appl. Genet, 98, 602- 607.

Chaudhary, S. A. (2001) "Flora of the Kingdom of Saudi Arabia". Illustrated vol.2 (part2) Ministry of Agriculture and Water, Kingdom of Saudi Arabia.

Collonette, S. (1999) "Wild Flowers of Saudi Arabia". National Commission for Wildlife Conservation and Development (NCWCD). Kingdom of Saudi Arabia.

Dice, L.R. (1945) Measures of the amount of ecological association between species. Ecology, 26, 297-302.

Florina, F. (2012) Assessment of genetic diversity in a collection of local tomatoes by SDS-PAGE method. Journal of Horticulture, Forestry and Biotechnology, 16 (3), 133- 136.

Hasan, S. M. Z. and Isa, M. L. (1998) Variability in eggplant (Solanum melongena L. ) and its nearest wild species as revealed by polyacryl amide gel electrophoresis of seed protein. Pertanika J. Tr ap. Agric. Sci., 21(2), 113 -122.

Isshiki, S., Iwataa, N. and Khana, M.M.R. (2008) ISSR variations in eggplant (Solanum melongena L.) and related Solanum species. Sci. Hort., 117, 186-190.

Jaeger, P-ML. (1985) Systematic studies in the genus Solanum in Africa. PhD thesis. University of Birmingham, UK.

Karihaloo, J.L., Brauner, S., and Gottlieb, L.D. (1995) Random amplified polymorphic DNA variation in the eggplant Solanum melongena L. Theor. Appl. Genet., 90, 767770.

Karihaloo, J.L. and Gottlieb, L.D. (1995) Allozyme variation in the eggplant Solanum melongena L. (Solanaceae). Theor. Appl. Genet., 90, 578-583.

Karihaloo, J.L., Kaur, M., and Singh, S. (2004) Seed protein diversity in Solanum melongena and its wild and weedy relatives. Genetic Resources and Crop Evolution, 49, 533-539.

Laemmli, U.K. (1970) Cleavage of structural proteins during assembly of head bacteriophage T4. Nature, 227, 680-685.

Li, H., Chen, H., Zhuang, T. and Chen, J. (2010) Analysis of genetic variation in eggplant and related Solanum species using sequence-related amplified polymorphism markers. Scientia Horticulturae , 125 (1), 19-24.

Miller, J.T., and Spooner, D. M. (1999) Collapse of species boundaries in the wild potato Solanum brevicaule Complex (Solanaceae sect. Petota): Molecular Data. Pl. Syst. Evo., 214, 103-130. 
Sandra, M., Fernanda, S., José, M., Ana, S. and Valdemar, C. (2014) Genetic relationship among wild, landraces and cultivars of hazelnut (Corylusavellana) from Portugal revealed through ISSR and AFLP markers. Plant Systematics \& Evolution, 300 (5), p1035.

Sheidai, M., Goldasteh, M. and Khatamsaz, M. (2002) Cytology and seed protein analysis of Solanaceae species in Iran. Nucleus CATINIST, 45, 36-43.

Singh, A.K., Singh, M., Singh, A.K., Singh, R., Kumar, S. and Kalloo, G. (2006) Genetic diversity within the genus Solanum (Solanaceae) as revealed by RAPD markers. Current science, 90, 5, 711-716.

SPSS. (2011) SPSS Statistics for Windows. Version 20.0. Chicago, IL, USA, SPSS Inc.

Stedje, B. and Bukenya-Ziraba, R. (2003) RAPD Variation in Solanum anguivi Lam. and S. aethiopicum L. (Solanaceae) in Uganda. Euphytica, 131, 293-297.

Viorel, M., Mann, A., Loana, M., Rodica, P., Lehel, L. and Mirela, C. (2009) Genotypic variability of several plum cultivars grown in transylvania evaluated by means of RAPD Analysis. Bulletin of the University of Agricultural Sciences \& Veterinary, 66 (1), p79.

Whalen, M.D. (1979) Speciation in Solanum, section Androceras. "In The Biology and Taxonomy of the Solanaceae" (Eds Hawkes, J. G., Lester, R. N. and Skelding, A. D.), Linnean Society Symposium Series, London Academic Press, vol. 7, pp. 581-596.

Williams, J.K.F., Kubelik, A.R., Livak, K.G., Rafalski, J.A. and Tingey, S.V. (1990) DNA Polymorphisms amplified by arbitrary primers is useful as genetic markers. Nucl. Acids Res., 18, 6531-6535.

Zabihollah, Z., Ali, S., Reza, F. and Naser, B. (2012) Genetic relatedness among some wild cherry (Prunus subgenus Cerasus) genotypes native to Iran assayed by morphological traits and random amplified polymorphic DNA analysis. Plant Systematics \& Evolution, 298 (2), 499. 


\section{التباين الوراثى داخل جنس السولانم فى مرتفعات الطائف اعتمادا على تقنية قطع الدنا المكثرة عشوائيا}

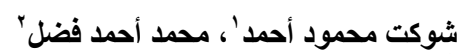

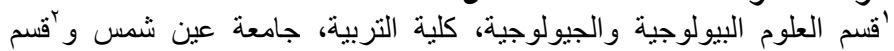
النبات، كلية العلوم، جامعة بنى سويف.

جنس السولانم جنس كبير ينتمى للعائلة الباذنجانية ويشتمل على اثثين من الإنها

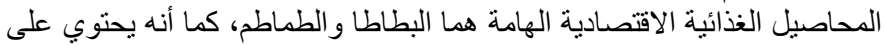

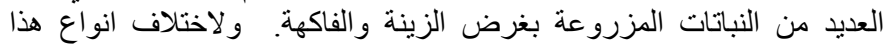

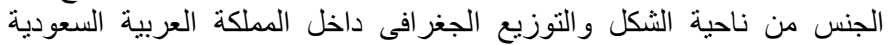

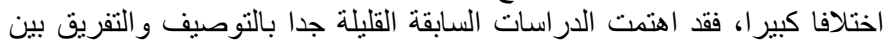

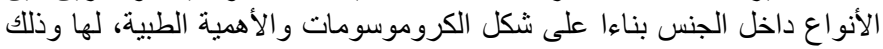

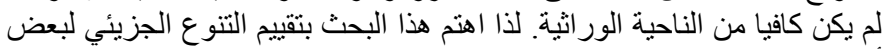

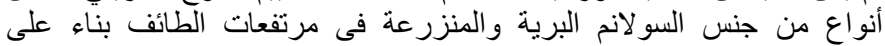

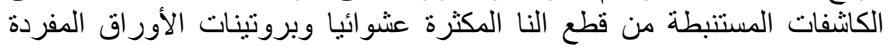

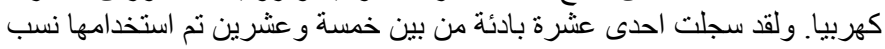

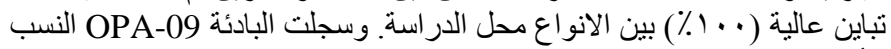
الأعلى فى حين سجلت البادئات

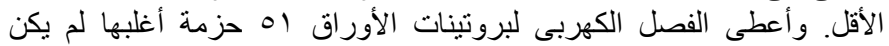

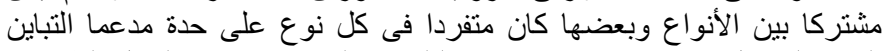

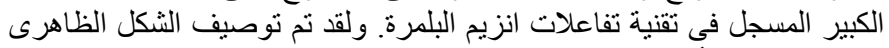

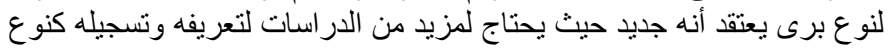

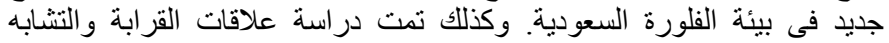
الجينى بين بعض الأنواع البرية والمنزر عة داخل جنس السو لانم. 